\title{
FIELD TRIALS WITH CERTAIN ENTOMOPATHOGENS AND INSECTICIDES AGAINST BERSEEM CHECKED GRASSHOPPER Euprepocnemis plorans (CHARP.) $\left(\begin{array}{c}\text { against plagiarism } \\ \text { using } \\ \text { Turnittn }\end{array}\right.$ (ORTOPTERA: ACRIDIDAE) \\ Abdelatef, G. M. \\ Plant Prot. Res. Inst., A. R. C., Dokki, Giza Egypt. \\ E-mail: gamalabdelatef@yahoo.com
}

\begin{abstract}
Three field trials were conducted to evaluate three entomopathogens (Metarhizium acridum, Beauveria bassiana and Nosema locustae) and two chemical insecticides (Indoxacarb and Fipronil) against berseem grasshoppers Euprepocnemis plorans (Charp.). Results from the first trial indicated that both $M$. acridum and $N$. locustae are successful pathogens against grasshoppers in the field but their effect was slow, while both Indoxacarb and Fipronil are effective insecticides aginst $E$. plorans in the field when used as spray or bait techniques. Moreover, results from second trial showed that mixtures of $M$. acridum with low dose $(10 \%$ of recommended dose) of Indoxacarb and Fipronil caused acceleration in grasshopper mortality when used as spray technique. In the third trial the obtained results showed that $N$. locustae mixtures with Indoxacarb and Fipronil also caused acceleration in grasshopper's mortality. It could be concluded that using $M$. acridum and $N$. locustae in combination with low dose (10\% of recommended dose) of Indoxacarb and Fipronil could achieve environmentally safe control operation, moreover Indoxacarb and Fipronil could be used in grasshoppers control as new group of insecticides in replacement of classical groups of insecticides.
\end{abstract}

Keywords: Metarhizium acridum, Beauveria bassiana, Nosema locustae, locusts, grasshoppers, Biological Control, IPM

\section{INTRODUCTION}

Among the species of grasshoppers known in Egypt only two species of grasshoppers cause a serious damage to cultivated crops especially in the new reclaimed lands. These are Euprepocnemis plorans (Charp.) and Heteracris annulosa (Walker) (Orthoptera : Acrididae) Nakhla, (1957). Recently, survey studies of Plant Protection Institute, showed clearly that high population of grasshopper $E$. plorans was found infesting cultivated clover Trifolium alexandrinum at Atmeda village, Dakahlia Governorate.

Interest in using entomopathogens as biological control agents has grown since the last major locust plague of the 1980s. Millions liters of chemical pesticides were used to combat this plague, which led to an outcry among environmental groups Greathead, (1992 a). Locust and grasshoppers like most of insects are host to numerous microorganisms, the most extensively studied entomopathogens were the microsporidian, Nosema locustae and the deuteromycete fungi Metarhizium acridum (=M. anisopliae var. acridum) and Beauveria bassiana Greathead, (1992 b) and Lobo Lima et al., (1992). All fungi isolates found highly virulent to locust and grasshoppers are in the genus Metarhizium and have originated from Orthoptera. The 
isolate that was adopted as a standard and used in all assays for comparison is M. acridum IMI330189 originated from the grasshopper Ornithacris cavroisi (Finot) collected in Niger. No high virulent isolates to locust have yet been found originating in non orthopteran hosts Prior, (1992). M. acridum proved to be successful biocontrol agent against desert locust and grasshoppers under Egyptian conditions but it's relative slow of action might be disadvantage of this fungi when making control operation (Abdelatef, 2005), this conclusion could be apply also for most entomopathogens.

Highly efficacious insecticides with novel modes of action (i.e. indoxacarb) are becoming increasingly important in agriculture as components of integrated pest management to replace older classes of compounds which are perceived to carry higher environmental risk (Wing et al., 2000). Indoxacarb is newly developed insecticide, it is highly active broad spectrum insecticide when directly administered topically or orally to pest insects (Harder et al., 1997). Fipronil is a phenylpyrazole insecticide with novel mode of action that targets the GABA-gated chloride channel in nervecell membranes and is highly toxic to arthropods. Unlike many modern pesticides, fipronil and its derivatives are moderately persistent in the environment (Chandler et al., 2004). Fipronil at low dosage provides longterm protection against major lepidopterous and orthopterous pests on crops (Colliot et al., 1992 and Burris et al., 1994).

Aim of this work is to evaluate the efficacy of two entomopathogenic fungi $M$. acridum and $B$. bassiana and the microsporidian, $N$. locustae and two insecticides fipronil and indoxacarb against $E$. plorans, also the combination between entomopathogens and insecticides, to achieve integrated pest management program for E. plorans.

\section{MATERIALS AND METHODS}

\section{Entomopathogens}

The fungi $M$. acridum strain IMI330189 (kindly provided by Basf South Africa under commercial name Green Muscle). It was used at rate of $25 \mathrm{~g}$. spores/ha.

The spores of $B$. bassiana were originally isolated from adult cadavers of the red palm weevil Rhynchophorus ferrugineus Oliv. collected from ElKassasien area, El-Esmaalia Governorate Heikal, (2001) and passaged in grasshoppers and desert locust for sevral passages in laboratory. It was used at rate of $25 \mathrm{~g}$. spores/ha.

The microsporidian $N$. locustae (obtained from Rangeland insect Laboratory, Bozeman Montana State USA), used at rate of $1.4 \times 10^{9}$ spores $/ 100 \mathrm{~g}$ of wheat bran $/ \mathrm{m}^{2}$ according to Henry, (1971).

\section{Insecticides}

Indoxacarb (15\% EC) under the commercial name Avaunt produced by DuPont, used at rate of $238 \mathrm{ml} / \mathrm{ha}$

Fipronil (20\% SC) under the commercial name Regent produced by Basf, used at rate of $238 \mathrm{ml} / \mathrm{ha}$.

Treatments

Three trials were done at Atmeda village, Dakahlia Governorate, 
against grasshopper E. plorans plorans, the grasshopper population were consist of $4^{\text {th }}$ and $5^{\text {th }}$ nymphal instars and adults. All treatments were applied to heavily infested areas with grasshoppers and planted with clover $T$. alexandrinum (which left to produce seeds), each plot varied in their size, ranged between 500-1000 $\mathrm{M}^{2}$. Two types of application were done, spray for fungi and the 2 insecticides and baits for the protozoa and the 2 insecticides. The spray solutions were consist of the applied treatment and $0.05 \%$ Tween 80 and applied using Cifarelli knapsack mist blower sprayer. While baits were, consist of the applied treatments + wheat bran $+5 \%$ mollas and applied manually at the edges of treated plots. After each treatment, samples of treated insects were collected and kept in cages under the field conditions, each cage was feed same plants of same treated area, while in bait treatment some of same bait was kept in cages for 3 days, the mortalities were recorded daily. In addition, grasshopper's populations were counted in field by counting number of grasshoppers in four virtual square meters, by walking a transect and making quadrate counts of the number of living grasshoppers in $1 \mathrm{~m}^{2}$ within the target area and the average number was calculated. An imaginary $1 \mathrm{~m}^{2}$ quadrate can be estimated by spreading the feet apart to form a base almost $1 \mathrm{~m}$ wide (Dobson, 2001).

\section{First trial}

The following treatments were done at the recommended doses: $1-M$. acridum (spray) 2- B. bassiana (spray) 3- N. locustae (bait) 4- Indoxacarb (spray) 5- Fipronil (spray) 6- Indoxacarb (bait) 7- Fipronil (bait).

\section{Second trial}

In this trial the following treatments were done as previously mentioned: $1-$ M. acridum + Indoxacarb (10\% of recommended dose) 2Indoxacarb (10\% of recommended dose). 3- M. acridum + Fipronil (10\% of recommended dose) 4 -Fipronil (10\% of recommended dose).

Third trial

While in third trial the following treatments were done: $1-N$. locustae+ Indoxacarb (10\% of recommended dose) 2-Indoxacarb (10\% of recommended dose). 3- N. locustae + Fipronil (10\% of recommended dose) $4-F i p r o n i l(10 \%$ of recommended dose).

\section{Statistics}

To calculate the efficacy of the tested control agents, the mortality of caged grasshoppers were subjected to Schneider-Orelli formula as following (Püntener 1981):

The efficacy $\%=($ Mortality $\%$ in treatment - Mortality $\%$ in control $) /(100$ Mortality \% in control) $X 100$

While those data from field counting were subjected to Analyses of Variance using costat 6.4 software from CoHort Software, 2 way completely randomized procedure was utilized.

\section{RESULTS AND DISCUSSION}

\section{First trial:}

Table (1) and Fig. (1) show corrected mortality of first trial treatment of caged insects, it's clear that both used insecticides treatments as spray or bait caused $100 \%$ mortality within four to seven days after treatment, also 
bait treatments take about 1-2 days longer than spray treatments to reach $100 \%$ mortality. While the used entomopathogens act slowly where $M$. acridum, B. bassiana and $N$. locustae caused $84.08,41.49,77.66 \%$ mortality by the $14^{\text {th }}$ day post treatment.

While data in Table (2) and Fig (2) show number of grasshoppers per square meter in the treated plots as well as control treatment. These data clearly rival that Indoxacarb as spray and reagent as spray reached to $100 \%$ reduction ( 0 grasshoppers $/ \mathrm{m}^{2}$ ) by day 2 and 3 respectively, while in bait treatments it were 5 and 6 days post treatment. But in $M$. acridum, $B$. bassiana and $N$. locustae by the $14^{\text {th }}$ day post treatment number of grasshoppers $/ \mathrm{m}^{2}$ were decreased to $1,3.75$, and 2 .

\section{Second trial:}

In this trial, the efficacy of $M$. acridum mixed with $10 \%$ of recommended dose of both used insecticides was evaluated. Obviously data in Table (3) and Fig. (3), show that mixing $M$. acridum with low dose of both used insecticides caused acceleration in grasshopper mortality in compare with the application of used insecticides at low dose and $M$. acridum alone. The mortality in $M$. acridum + Indoxacarb and $M$. acridum + Fipronil reached to 88 and $89 \%$ by the $3^{\text {rd }}$ day post treatment, respectively, while the mortality reached to $100 \%$ by the $8^{\text {th }}$ and $7^{\text {th }}$ day post treatment. While in case of Indoxacarb and Fipronil alone the mortality reached to 75 and $69.79 \%$ by the $11^{\text {th }}$ and $10^{\text {th }}$ day post treatment, respectively.

Table (4) and Fig (4) show number of grasshoppers per square meter, it is clear that mixtures of $M$. acridum with both used insecticides (Indoxacarb and Fipronil) at low doses caused $100 \%$ reduction by the $7^{\text {th }}$ and $6^{\text {th }}$ day post treatment. While in case of application of Indoxacarb and Fipronil at low doses alone reached to $100 \%$ reduction by the $9^{\text {th }}$ day post treatment.

\section{Third trial}

The third trial was conducted to test the efficacy of $N$. locustae mixtures with Indoxacarb and Fipronil at low doses as baits application. Table (5) and Fig. (5) Show the corrected mortality of $N$. locustae mixtures and both used insecticides. It is clear that, $N$. locustae and Indoxacarb mixture caused 77.55 $\%$ mortality after 5 days and $N$. locustae and Fipronil mixture caused $79.38 \%$ mortality after 7 days, however in Indoxacarb and Fipronil sole treatments at low dose reached 75 and $72.92 \%$ by day 10 post treatment, respectively.

Table (6) and Fig. (6) show the mean number of grasshoppers per square meter, it is clear that in N. locustae + Indoxacarb and N. locustae + Fipronil treatment the reduction in grasshoppers numbers reached to $100 \%$ after 8 and 7 days post treatment, respectively, while in case of Indoxacarb and Fipronil sole treatments $100 \%$ reduction occurred at day 12 post treatment.

M. acridum (applied as spray technique) was the most virulent entomopathogen against $E$. plorans in the field followed by $N$. locustae (applied as bait technique), several virulence screening tests and trials using M. acridum IMI 330189 revealed that $94 \%$ of 17 different orthopteran species were susceptible, and $95 \%$ - all within acrididae- highly susceptible (Prior, 1997). Many authors reported field efficacy of $M$. acridum against grasshoppers species and confirmed the results of the present study for 
example against Variegated grasshopper Zonocerus variegates in Benin (Lomer et. al., 1993 and Douro-Kpindou et. al., 1995), against Wingless grasshopper Phaulacridum vittatum in Australia (Baker et. al., 1994 and Milner et. al., 1994), against grasshoppers particularly Rice grasshopper Hieroglyphus daganensis, in northern Benin (Lomer et. al., 1997) and against Sahelian grasshoppers (Kooyman et. al., 1997).

Unlike chemical pesticides pathogens are slow acting agent as discovered in the present work, Kooyman and Godonou, (1997), Bateman et al., (1993) and Abdelatif, (2005) have pointed out how difficult it is to convincingly demonstrate field efficacy with slow acting agent against desert locust and other grasshoppers species using entomopathogens.

Fipronil is a relatively new insecticide that controls a broad spectrum of insects at low field application rates. It is a "new generation" insecticide because its mode of action, interference with the normal function of $\mathrm{g}$ aminobutyric acid (GABA)-gated channels, differs from the classical insecticides, such as organophosphates and carbamates (Gunasekara, et al., 2007), it has been proposed as a replacement for dieldrin to control desert locusts, (Balanca and de Visscher, 1997). The present work proved also that fipronil affective against $E$. plorans in the field when applied as spray or bait, it could be used against grasshopper in replacement of old pesticides groups.

Indoxacarb is a promising new foliar insecticide with strong field activity against Lepidoptera, a key feature of this compound is its novel bioactivation, then block off the insect voltage-gated sodium channel by the $\mathrm{N}$ decarbomethoxyllated metabolite (Wing et al., 2000). Indoxacarb approved it is efficiency against $E$. plorans in the present work when used as spray or bait technique.

The results of the $2^{\text {nd }}$ and $3^{\text {rd }}$ trials strongly show that mixtures of $M$. acridum or $N$. locustae with indoxacarb or fipronil can be an effective and economic alternative to the use of particular control agents alone. Sub lethal doses of fipronel were reported by many authors to be affective against locusts and grasshoppers, (Balanqa and de Visscher, 1997 and Lecoq and Balanqa, 1997). While sub lethal doses of indoxacarb affected larval pupation and adult longevity and fecundity of Spodoptera litura (Wang et al., 2009) also effect on the mortality of Formosan subterranean termite Coptotermes formosanus workers (Hu et al., 2005). The sub lethal doses of chemicals give almost immediate crop protection in same time provide the entomopathogens more time to kill grasshoppers. Apparently the low rate insecticides stress the target or alter their behaviour in such a way as to make it more susceptible to the entomopathogens. The final conclusion of the present study is that, application of entomopathogens and subletha doses of insecticides had the typical knockdown effect of a conventional insecticide that convinces farmers, while the biopesticide component maintained low population densities throughout the duration of the trial, and this even at 1/10 of the recommended dose. 
Table (1) Accumulative corrected mortality percentages of caged insects from first trial

\begin{tabular}{|l|c|c|c|c|c|c|c|}
\hline Treatments & $\begin{array}{c}\boldsymbol{M} . \\
\text { acridum }\end{array}$ & $\begin{array}{c}\text { B. } \\
\text { bassiana }\end{array}$ & $\begin{array}{c}\boldsymbol{N} . \\
\text { locustae }\end{array}$ & $\begin{array}{c}\text { Indoxacarb } \\
\text { (spray) }\end{array}$ & $\begin{array}{c}\text { Fipronil } \\
\text { (spray) }\end{array}$ & $\begin{array}{c}\text { Indoxacarb } \\
\text { (bait) }\end{array}$ & $\begin{array}{c}\text { Fipronil } \\
\text { (bait) }\end{array}$ \\
\hline 0 & 0.00 & 0.00 & 0.00 & 0.00 & 0.00 & 0.00 & 0.00 \\
\hline 1 & 1.00 & 1.00 & 0.00 & 52.00 & 50.00 & 42.00 & 34.00 \\
\hline 2 & 1.00 & 1.00 & 1.00 & 94.00 & 78.00 & 63.00 & 61.00 \\
\hline 3 & 4.04 & 3.03 & 0.00 & 97.98 & 89.90 & 78.79 & 83.84 \\
\hline 4 & 11.22 & 6.12 & 0.00 & 100.00 & 94.90 & 94.90 & 91.84 \\
\hline 5 & 17.35 & 11.22 & 2.04 & & 98.98 & 98.98 & 93.88 \\
\hline 6 & 23.47 & 16.33 & 2.04 & & 100.00 & 100.00 & 96.94 \\
\hline 7 & 27.84 & 19.59 & 4.12 & & & & 100.00 \\
\hline 8 & 31.25 & 22.92 & 7.29 & & & & \\
\hline 9 & 38.54 & 26.04 & 17.71 & & & & \\
\hline 10 & 46.88 & 29.17 & 30.21 & & & & \\
\hline 11 & 58.33 & 32.29 & 41.67 & & & & \\
\hline 12 & 65.26 & 34.74 & 52.63 & & & & \\
\hline 13 & 72.63 & 38.95 & 66.32 & & & & \\
\hline 14 & 84.04 & 41.49 & 77.66 & & & & \\
\hline
\end{tabular}

Table (2) Mean number of grasshoppers per square meter from first trial

\begin{tabular}{|l|c|c|c|c|c|c|c|c|}
\hline & Control & $\begin{array}{c}\boldsymbol{M} \text {. } \\
\text { acridum }\end{array}$ & $\begin{array}{c}\text { B. } \\
\text { bassiana }\end{array}$ & $\begin{array}{c}\boldsymbol{N} \text {. } \\
\text { locustae }\end{array}$ & $\begin{array}{c}\text { Indoxacarb } \\
\text { (spray) }\end{array}$ & $\begin{array}{c}\text { Fipronil } \\
\text { (spray) }\end{array}$ & $\begin{array}{c}\text { Indoxacarb } \\
\text { (bait) }\end{array}$ & $\begin{array}{c}\text { Fipronil } \\
\text { (bait) }\end{array}$ \\
\hline 0 & 9.00 & 9.50 & 9.25 & 8.75 & 8.75 & 8.50 & 9.50 & 9.50 \\
\hline 1 & 9.25 & 8.75 & 8.75 & 8.25 & $1.00^{*}$ & $1.25^{*}$ & $4.50^{*}$ & $4.50^{*}$ \\
\hline 2 & 9.25 & 8.25 & $7.75^{*}$ & 8.00 & $0.00^{*}$ & $1.00^{*}$ & $2.25^{*}$ & $2.00^{*}$ \\
\hline 3 & 9.75 & 8.00 & 8.50 & $7.50^{*}$ & & 0.00 & $1.00^{*}$ & $1.00^{*}$ \\
\hline 4 & 9.50 & $7.00^{*}$ & $7.75^{*}$ & $7.50^{*}$ & & & $0.50^{*}$ & $0.75^{*}$ \\
\hline 5 & 9.50 & $6.00^{*}$ & $7.50^{*}$ & $7.75^{*}$ & & & 0.00 & $0.75^{*}$ \\
\hline 7 & 9.75 & $5.25^{*}$ & $7.25^{*}$ & 8.00 & & & & 0.00 \\
\hline 8 & 9.00 & $5.00^{*}$ & $7.00^{*}$ & $7.00^{*}$ & & & & \\
\hline 10 & 9.25 & $4.00^{*}$ & $6.25^{*}$ & $7.50^{*}$ & & & & \\
\hline 11 & 9.50 & $4.00^{*}$ & $5.75^{*}$ & $7.75^{*}$ & & & & \\
\hline 12 & 9.75 & $3.25^{*}$ & $5.75^{*}$ & $7.00^{*}$ & & & & \\
\hline 13 & 10.00 & $2.75^{*}$ & $5.25^{*}$ & $5.25^{*}$ & & & & \\
\hline 14 & 10.00 & $2.25^{*}$ & $5.00^{*}$ & $4.25^{*}$ & & & & \\
\hline
\end{tabular}

Means with * are significantly lower than control 
Table (3) Accumulative corrected mortality percentages of caged insects from second trial

\begin{tabular}{|l|c|c|c|c|}
\hline Treatments & $\begin{array}{c}\text { M. acridum + } \\
\text { Indoxacarb } \\
\text { (10\% of } \\
\text { recommended } \\
\text { dose) }\end{array}$ & $\begin{array}{c}\text { Indoxacarb } \\
\text { (10\% of } \\
\text { recommended } \\
\text { dose) }\end{array}$ & $\begin{array}{c}\text { M. acridum + } \\
\text { Fipronil } \\
\text { (10\% of } \\
\text { recommended } \\
\text { dose) }\end{array}$ & $\begin{array}{c}\text { Fipronil } \\
\text { (10\% of } \\
\text { recommended } \\
\text { dose) }\end{array}$ \\
\hline 0 & 0.00 & 0.00 & 0.00 & 0.00 \\
\hline 1 & 37.00 & 16.00 & 43.00 & 17.00 \\
\hline 2 & 64.00 & 28.00 & 66.00 & 31.00 \\
\hline 3 & 88.00 & 42.00 & 89.00 & 43.00 \\
\hline 4 & 95.96 & 48.48 & 95.96 & 50.51 \\
\hline 5 & 95.92 & 51.02 & 96.94 & 53.06 \\
\hline 6 & 95.92 & 54.08 & 97.96 & 57.14 \\
\hline 7 & 98.98 & 59.18 & 100.00 & 60.20 \\
\hline 8 & 100.00 & 59.79 & & 63.92 \\
\hline 9 & & 67.71 & & 66.67 \\
\hline 10 & & 73.96 & & 69.79 \\
\hline 11 & & 75.00 & & \\
\hline
\end{tabular}

Table (4) Mean number of grasshoppers per square meter from second trial

\begin{tabular}{|l|c|c|c|c|c|}
\hline Treatments & Control & $\begin{array}{c}\text { M. acridum + } \\
\text { Indoxacarb } \\
\text { (10\% of } \\
\text { recommended } \\
\text { dose) }\end{array}$ & $\begin{array}{c}\text { Indoxacarb } \\
\text { (10\% of } \\
\text { recommende } \\
\text { d dose) }\end{array}$ & $\begin{array}{c}\text { M. acridum + } \\
\text { Fipronil } \\
\text { (10\% of } \\
\text { recommended } \\
\text { dose) }\end{array}$ & $\begin{array}{c}\text { Fipronil } \\
\text { (10\% of } \\
\text { recommended } \\
\text { dose) }\end{array}$ \\
\hline 0 & 9.00 & 9.50 & 9.25 & 8.75 & 8.75 \\
\hline 1 & 9.25 & $4.00^{*}$ & $6.50^{*}$ & $4.00^{*}$ & $5.25^{*}$ \\
\hline 2 & 9.25 & $3.00^{*}$ & $5.75^{*}$ & $3.00^{*}$ & $4.50^{*}$ \\
\hline 3 & 9.75 & $2.50^{*}$ & $5.25^{*}$ & $2.50^{*}$ & $3.75^{*}$ \\
\hline 4 & 9.50 & $1.75^{*}$ & $4.50^{*}$ & $1.50^{*}$ & $3.50^{*}$ \\
\hline 5 & 9.50 & $1.50^{*}$ & $3.50^{*}$ & $0.50^{*}$ & $3.00^{*}$ \\
\hline 6 & 9.75 & $0.50^{*}$ & $3.00^{*}$ & 0.00 & $2.75^{*}$ \\
\hline 7 & 9.00 & 0.00 & $1.75^{*}$ & & $1.75^{*}$ \\
\hline 8 & 9.25 & & $0.50^{*}$ & & $0.50^{*}$ \\
\hline 9 & 9.50 & & 0.00 & & 0.00 \\
\hline 10 & 9.75 & & & & \\
\hline
\end{tabular}

Means with * are significantly lower than control 
Table (5) Accumulative corrected mortality percentages of caged insects from third trial

\begin{tabular}{|l|c|c|c|c|}
\hline Treatments & $\begin{array}{c}\text { N. locustae + } \\
\text { Indoxacarb (10 } \\
\text { \% of } \\
\text { recommended } \\
\text { dose) }\end{array}$ & $\begin{array}{c}\text { Indoxacarb } \\
\text { (10\% of } \\
\text { recommended } \\
\text { dose) }\end{array}$ & $\begin{array}{c}\text { N. locustae } \\
\text { Fipronil } \\
\text { (10\% of } \\
\text { recommended } \\
\text { dose) }\end{array}$ & $\begin{array}{c}\text { Fipronil } \\
\text { (10\% of } \\
\text { recommended } \\
\text { dose) }\end{array}$ \\
\hline 0 & 0.00 & 0.00 & 0.00 & 0.00 \\
\hline 1 & 26.00 & 14.00 & 20.00 & 12.00 \\
\hline 2 & 40.00 & 25.00 & 36.00 & 24.00 \\
\hline 3 & 52.53 & 36.36 & 49.49 & 36.36 \\
\hline 4 & 67.35 & 43.88 & 56.12 & 43.88 \\
\hline 5 & 77.55 & 47.96 & 62.24 & 47.96 \\
\hline 6 & 82.65 & 52.04 & 72.45 & 52.04 \\
\hline 7 & 83.51 & 57.73 & 79.38 & 56.70 \\
\hline 8 & & 59.38 & 83.33 & 63.54 \\
\hline 9 & & 68.75 & & 69.79 \\
\hline 10 & & 75.00 & & 72.92 \\
\hline
\end{tabular}

Table (6) Mean number of grasshoppers per square meter from third trial

\begin{tabular}{|l|c|c|c|c|c|}
\hline Treatments & Control & $\begin{array}{c}\text { N. locustae + } \\
\text { Indoxacarb } \\
\text { (10\% of } \\
\text { rocommended } \\
\text { dose) }\end{array}$ & $\begin{array}{c}\text { Indoxacarb } \\
(\mathbf{1 0 \%} \text { of } \\
\text { recommended } \\
\text { dose) }\end{array}$ & $\begin{array}{c}\text { N. locustae + } \\
\text { Fipronil } \\
(\mathbf{1 0} \% \text { of } \\
\text { recommended } \\
\text { dose) }\end{array}$ & $\begin{array}{c}\text { Fipronil } \\
\text { (10\% of } \\
\text { recommended } \\
\text { dose) }\end{array}$ \\
\hline 0 & 9.00 & 8.25 & 8.25 & 8.75 & 8.50 \\
\hline 1 & 9.25 & $7.00^{*}$ & $7.25^{*}$ & $7.50^{*}$ & $6.50^{*}$ \\
\hline 2 & 9.25 & $6.50^{*}$ & $6.00^{*}$ & $6.25^{*}$ & $5.75^{*}$ \\
\hline 3 & 9.75 & $5.75^{*}$ & $5.25^{*}$ & $5.25^{*}$ & $5.25^{*}$ \\
\hline 4 & 9.50 & $4.25^{*}$ & $4.50^{*}$ & $2.75^{*}$ & $4.00^{*}$ \\
\hline 5 & 9.50 & $2.25^{*}$ & $3.75^{*}$ & $2.25^{*}$ & $3.25^{*}$ \\
\hline 6 & 9.75 & $1.50^{*}$ & $2.75^{*}$ & $1.00^{*}$ & $3.00^{*}$ \\
\hline 7 & 9.00 & $0.75^{*}$ & $2.75^{*}$ & 0.00 & $2.75^{*}$ \\
\hline 8 & 9.25 & 0.00 & $2.25^{*}$ & & $2.00^{*}$ \\
\hline 10 & 9.50 & & $2.00^{*}$ & & $1.75^{*}$ \\
\hline 11 & 9.75 & & $1.50^{*}$ & & $1.67^{*}$ \\
\hline 12 & 10.00 & & $1.00^{*}$ & & $1.00^{*}$ \\
\hline & 10.00 & & 0.00 & & 0.00 \\
\hline
\end{tabular}

Means with * are significantly lower than control 


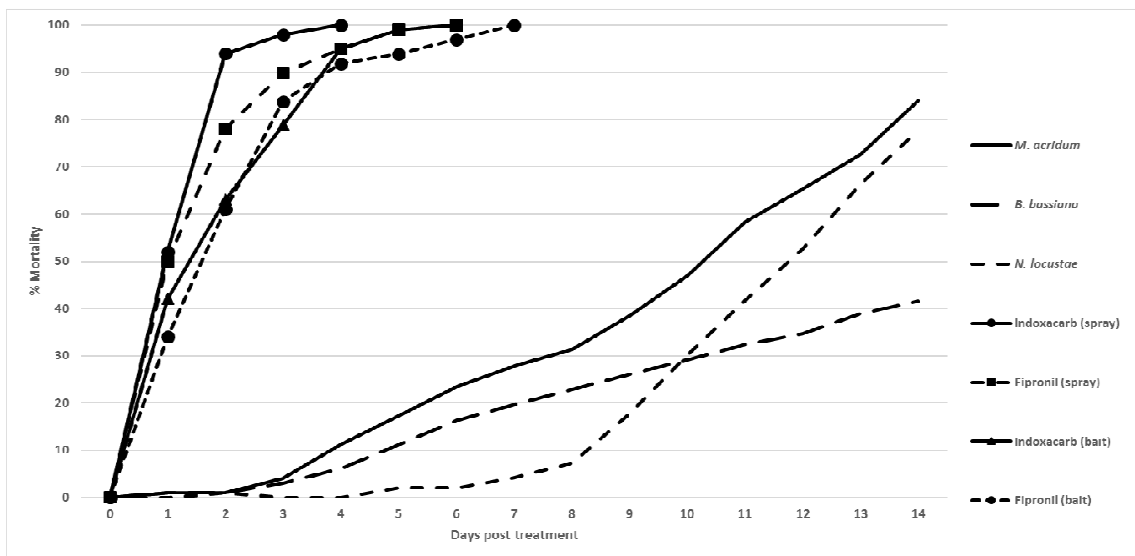

Figure (1) Accumulative corrected mortality percentages of caged insects from first trial

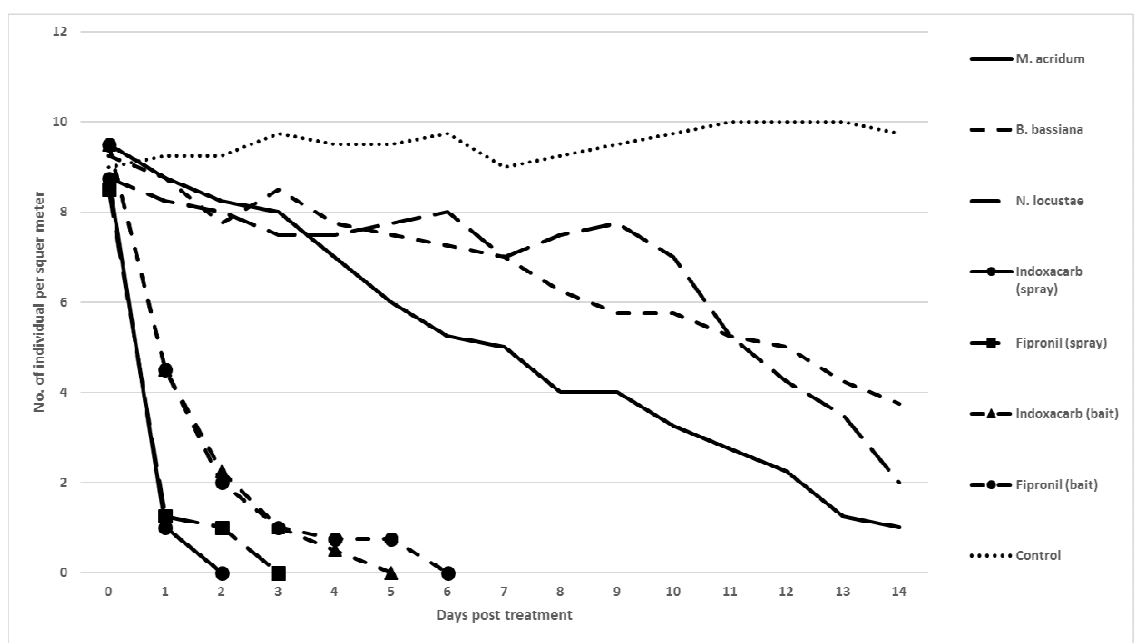

Figure (2) Accumulative corrected mortality percentages of caged insects from first trial 
Abdelatef, G. M.

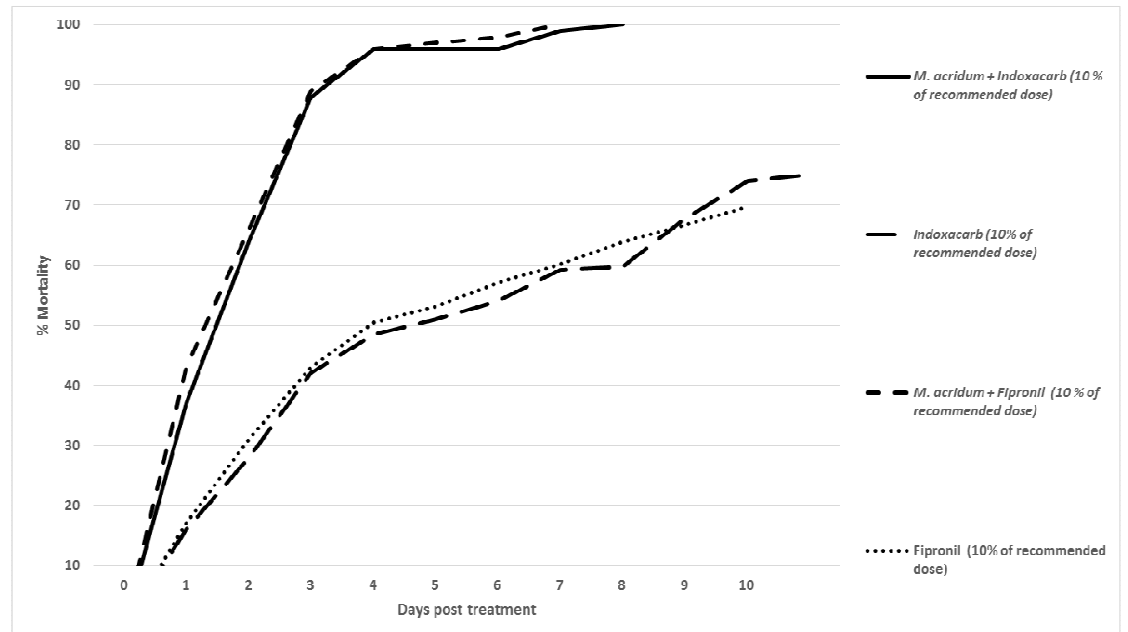

Figure (3) Accumulative corrected mortality percentages of caged insects from second trial

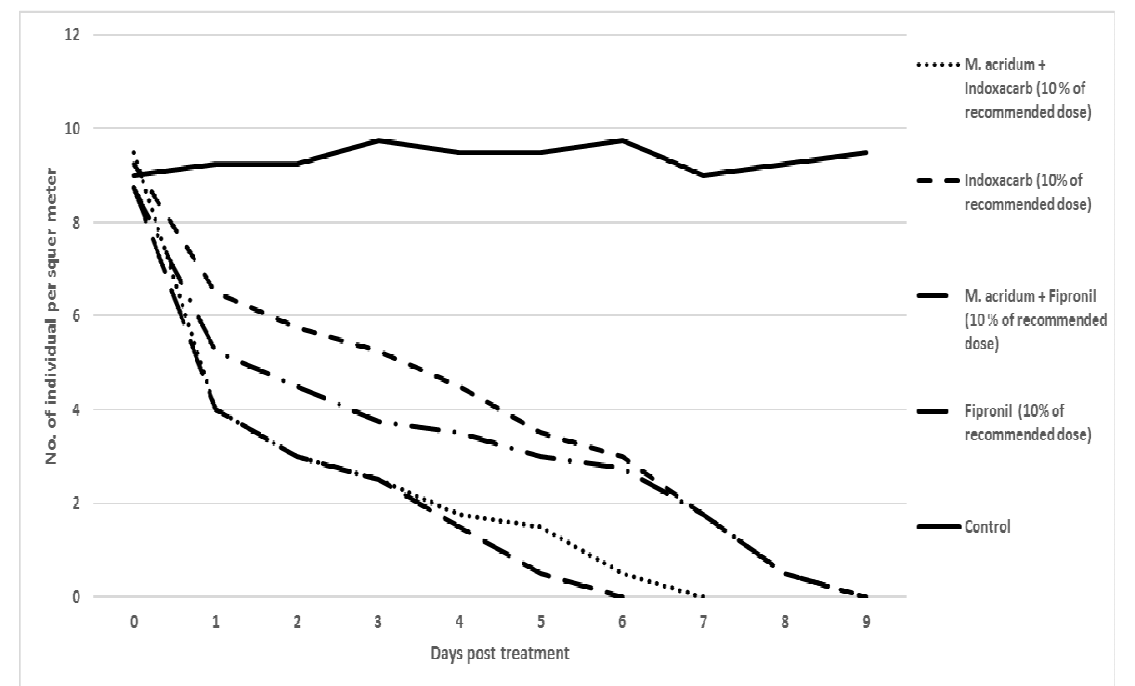

Figure (4) Mean number of grasshoppers per square meter from second trial 


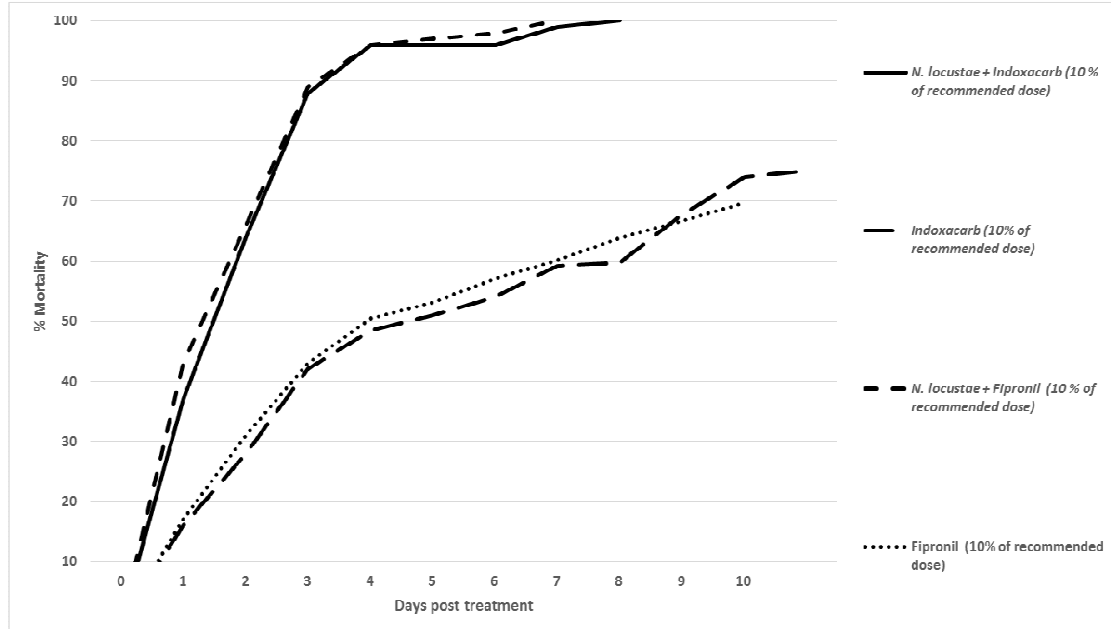

Figure (5) Accumulative corrected mortality percentages of caged insects from third trial

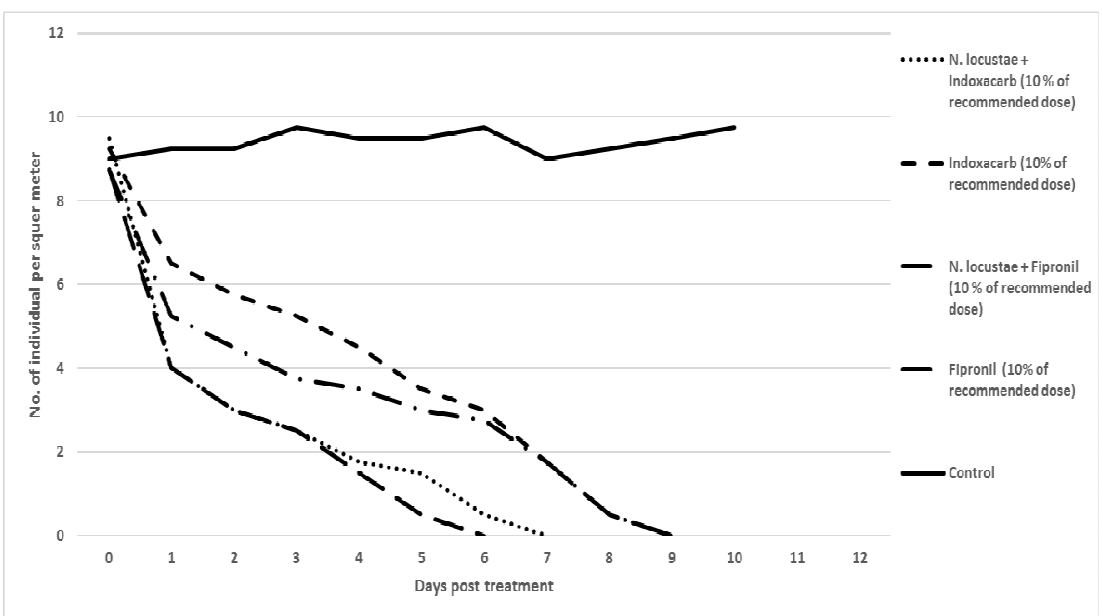

Figure (6) Mean number of grasshoppers per square meter from third trial 


\section{REFERENCES}

Abdelatif G. M., 2005. Effect of green muscle on locust and grasshoppers. Final report of project (FAO) CRC/EMPRES (PR27209). pp: 53.

Baker, G. L., R.J., Milner, G.G., Lutton and D. M., Watson,1994. Preliminary field trial on the control of Phaulacridum vittatum (Sjostetd) (Orthoptera: Acrididae) populations with Metarhizium flavoviride Gams and Rozsypal (Deuteromycetina: Hyphomycetes). Journal of the Australian Entomological Society. 33: 190-192.

Balanca G. and M. de Visscher 1997. Effect of very low doses of fipronil on grasshoppers and non- target insects following field trials for grasshopper control. Crop. Protection 16:553-564.

Bateman, R. P., M., Carey, D., Moore, and C., Prior, 1993. The enhanced infectivity of Metarhizium flavoviride in oil formulations to desert locusts at low humidities., Annals of Applied Biology. 122: 145-152.

Burris, E., B.R. Leonard, S.H. Martin, C.A. White, and J.B. Graves. 1994. Fipronil: Evaluation of soil and foliar treatments for control of thrips, aphids, plant bugs, and boll weevils. p. $838-844$. In D. J. Herber (ed.) Proc. Beltwide Cotton Insect Control Conf., San Diego, CA. January 1994. Natl. Cotton Council Am., Memphis, TN.

Chandler G. T.,T. L. Cary, D. C. Volz, S. S. Walse, J. L. Ferry, and S. L. Klosterhaus. 2004 Fipronil effects on estuarine copepod (amphiascus tenuiremis) development, fertility, and reproduction: a rapid life-cycle assay in 96-well microplate format. Environmental Toxicology and Chemistry 23: 117-124.

Colliot, F., K. A. Kukorowski, D. W. Hawkins, and D. A. Roberts. 1992. Fipronil: a new soil and foliar broad spectrum insecticide, pp. 29-34. In Proceedings, Brighton Crop Protection Conference: Pests and Diseases. British Crop Protection Council, Farnham, UK.

Dobson, H.M., 2001. Desert Locust Guidelines 4: Control. FAO pp: 85.

Douro-Kpindou, O. K., I., Godonou, A., Houssou, C. J., Lomer, and P.A., Shah, 1995. Control of Zonocerus variegatus by ultra-low volume application of an oil formulation of Metarhizium flavoviride conidia. Biocontrol science and technology. 5 (1): 131-139.

Greathead J., 1992 a. Keynote address biological control as potential tool for locust and grasshopper control. Biological control of locust and grasshoppers: Proceeding of workshop held at the international institute of Tropical Agriculture, Cotonou, Republic of Benin, $29^{\text {th }}$ April$1^{\text {st }}$ May 1991. 4-7.

Greathead J., 1992 b. Natural enemies of tropical locust and grasshopper : Their impact \& potential as biological control agents. Biological control of locust and grasshoppers: Proceeding of workshop held at the international institute of Tropical Agriculture, Cotonou, Republic of Benin, $29^{\text {th }}$ April- $1^{\text {st }}$ May 1991.105-121.

Gunasekara A. S., T. Truong, K. S. Goh, F. Spurlock and R. S. Tjeerdema 2007. Environmental fate and toxicology of fipronil J. Pestic. Sci., 32(3), 189-199. 
Harder, H.H., Riley, S. L., McCann, S.F. and Irving, S.N. 1997. DPX-MP062: A novel broad-sprectum, environmentally soft, insect control compound. In P. Dugger and D. Richter (eds), Proceedings of Beltwide Cotton Conferences, New Orieans. LA, USA, 6-10 January 1997 (Memphis: National Cotton Council). pp. 48-50.

Heikal, N. A. H., 2001. Studies on the red palm weevil (Biological, Pathological, and Physiological studies on the red palm weevil). MSc Theses. Zagazig University Faculty of Agriculture. 169 pp.

Henry, J. E., 1971. Experimental application of Nosema locustae for control of grasshoppers. J. Invert. Pathol. 18: 389-394.

Hu, X. P., D. Song and C. W. Scherer. 2005. Transfer of indoxacarb among workers of Coptotermes formosanus (Isoptera: Rhinotermitidae): effects of dose, donor: recipient ratio and post-exposure time. Pest Manag Sci 61:1209-1214.

Kooyman, C., Bateman, R.P., Langewald, J., Lomer, C.J., Ouambama, Z., Thomas, M.B. 1997. Operational-scale application of entomoentomopathogenic fungi for control of Sahelian grasshoppers. Proc. R. Soc. Lond., Biol. sci. 264: 541-546.

Kooyman, C., I., Godonou, 1997. Infection of Schistocerca gregaria (Orthoptera: Acrididae) hoppers by Metarhizium flavoviride (Deuteromycotina: Hyphomycetes) conidia in an oil formulation applied under desert conditions. Bulletin of Entomological Research. 87: 105107.

Lecoq M and G. Balanca, 1997. Field trials of fipronil for control of Rhammatocerus schistocercoides (Rehn, 1906) hopper bands in Brazil. Crop. Protection 17:105-110.

Lobo Lima, M.L. J.M., Brito, J.E., Henry, 1992. Biological control of grasshoppers in the Cape Verde Islands., In Lomer, C.J. and Prior, C. (eds.) Biological control of locust and grasshoppers. C.A.B. International/University of Arizona Press; Wallingford (UK)/Tucson, AZ (USA). pp. 287-295.

Lomer, C.J., Bateman, R.P., Godonou, I., Kpindou, D., Shah, P.A., Paraiso, A., and Prior, C., 1993. Field infection of Zonocerus variegatus following application of an oil-based formulation of Metarhizium flavoviride conidia. Biocontrol science and technology. 3 (3): 337-346.

Lomer, C.J., Thomas, M.B., Douro-Kpindou, O.K., Gbongboui, C., Godonou, I., Langewald, J. and Shah, P.A.. 1997. Control of grasshoppers, particularly Hieroglyphus daganensis, in northern Benin using Metarhizium flavoviride. Memoirs of the Entomological Society of Canada. 171: 301-311.

Milner, R.J.; Hartley, T.R.; Lutton, G.G.; Prior, C., 1994. Control of Phaulacridium vittatum (Sjoestedt) (Orthoptera: Acrididae) in field cages using an oil-based spray of Metarhizium flavoviride Gams and Rozsypal.

Nakhla, N. B., 1957. The life- history, habits and control of the bersim grasshopper, Euprepocnemis plorans Charp., in Egypt. Bull. Soc. Entomol. Egypt. 41: 411- 428. 
Prior C.,1992. Discovery and characterization of fungal entomopathogens for locust and grasshopper control. Biological control of locust and grasshoppers: Proceeding of workshop held at the international institute of Tropical Agriculture, Cotonou, Republic of Benin, $29^{\text {th }}$ April$1^{\text {st }}$ May 1991.8-18.

Prior, C., 1997. Susceptibility of target acridoids and non-target organisms to Metarhizium anisopliae and M. favoviride. New Strategies in Locust Control (ed. by S. Krall, R. Peveling and D. Ba Diallo), BirkhaĖuser Verlag, Basel, Switzerland. pp. 369-376.

Wang J. J., D. H. Gang and Y. LinZe. 2009. Effects of indoxacarb at sublethal concentrations on the development and activities of detoxification enzymes of Spodoptera litura. Journal of Yangzhou University, Agricultural and Life Sciences Edition 30 (4):85-89

Wing K. D., M. Sacher, Y. Kagaya, Y.Tsurubuchi, L. Mulderig, M. Connair, M. Schnee. 2000. Bioactivation and mode of action of the oxadiazine indoxacarb in insects Crop Protection 19:537-545.

تجارب حقليه لار اسة تأثير بعض المسببات المرضية الحشرية وبعض المبيدات الكيميائية

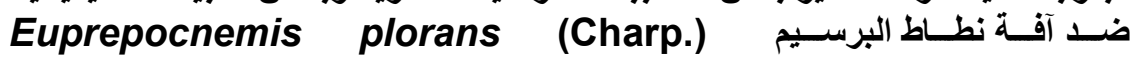
(Orthoptera: Acrididae)

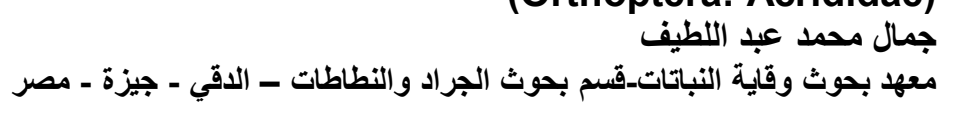

أجريت ثناث تجارب حقلية لتقييم تأثثير ات ثناثة مسببات مرضية حشريه Metarhizium) و و كذلك مبيدان حشريان . Euprepocnemis plorans ضـ آفة نطـاط البرسيم (Indoxacarb and Fipronil) أوضحت نتائج التجربه الأولى ان كل من M. acridum and N. locustae كانـا من المسببات

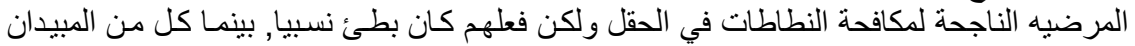

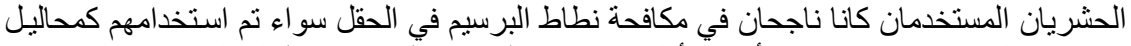

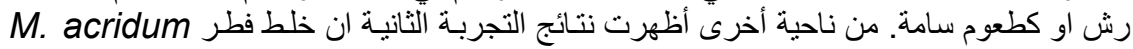

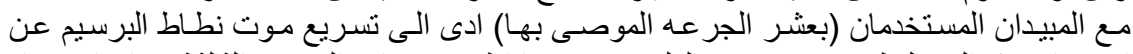

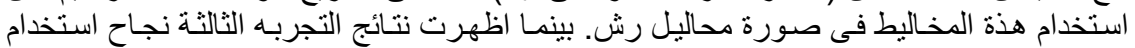

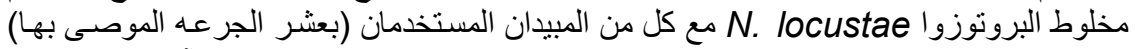

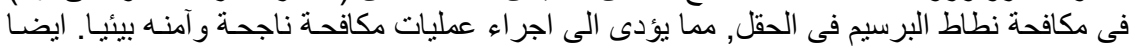

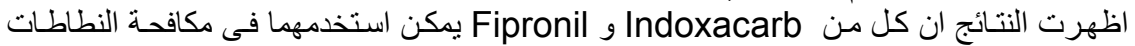
كبديل للمبيدات الكيميائية التقليدية. 